\title{
Two Siblings with Beta-Ketothiolase Deficiency: One Genetic Defect Two Different Pictures
}

\section{Beta-Ketotiolaz Eksikliği Tanısı Alan İki Kardeș: Tek Genetik Defekt Iki Farklı Tablo}

\author{
Melis Demir Köse1, Ebru Canda1, Mehtap Kağnıcı1, Rana İşgüder2, Aycan Ünalp3, \\ Sema Kalkan Uçar1, Luzy Bahr4, Corinne Britschgi4, Jörn Oliver Sass4, Mahmut Çoker4 \\ ${ }^{1}$ Ege University Faculty of Medicine, Department of Pediatric Metabolism, Izmir, Turkey \\ ${ }^{2}$ Behçet Uz Children Training and Research Hospital, Clinic of Pediatric Intensive Care, Izmir, Turkey \\ ${ }^{3}$ Behçet Uz Children Training and Research Hospital, Clinic of Neurology, Izmir, Turkey \\ 4Zürich University Children's Hospital, Department of Clinical Chemistry and Biochemistry, Zürich, Switzerland
}

\begin{abstract}
Deficiency of mitochondrial acetoacetyl-coenzyme A thiolase T2 (methylacetoacetyl-coenzyme A thiolase, MAT) or $\beta$-ketothiolase is a rare autosomal recessive disorder that is characterized by ketoacidosis episodes. Outcomes vary from normal development to severe cognitive impairment or even death after an acute episode of ketoacidosis. The classical biochemical profile of T2 deficiency is a result of mutations in both alleles of the ACAT1 gene and comprises characteristic abnormalities in urinary organic acids and blood or plasma acylcarnitine profiles. In this study, we present two sibling cases with quite different clinical properties.

Keywords: ACAT1 gene, beta-ketothiolase deficiency, encephalopathy, hyperammonemia, lactic acidosis
\end{abstract}

\section{$\ddot{O Z Z}$}

Mitokondriyal asetoasetil-koenzim A tiolaz T2 eksikliği (MAT- $\beta$-ketotiolaz) ketoasidotik ataklarla karakterize nadir bir otozomal resesif hastalıktr. Klinik gidişat tamamen normal gelişimsel süreçten ağır mental retardasyona hatta atak sonrası ölüme kadar değişebilir. Klasik T2 eksikliğinin idrar organik asit ve karnitin profiline yansıyan biyokimyasal özellikleri ACAT1 geninde her iki allelde de oluşacak mutasyonlar sonucu görülmektedir. Bu yazımızda oldukça farklı fenotipik özellikler gösteren ancak aynı mutasyonu paylaşan iki kardeşin bulguları tartışıımıştır.

Anahtar Kelimeler: ACAT1 geni, beta-ketotiolaz eksikliği, ensefalopati, hiperamonyemi, laktik asidoz

\section{Introduction}

Mitochondrial acetoacetyl-coenzyme A (CoA) thiolase deficiency (T2D) or methylacetoacetyl-CoA thiolase deficiency (MATD), commonly known as $\beta$-ketothiolase deficiency, is an autosomal recessive disease. Approximately 100 patients have been identified since 1971 (1). This disorder affects the catabolism of isoleucine and the metabolism of ketone bodies, and is clinically characterized by intermittent ketoacidosis attacks with no clinical symptoms between episodes (except for possible consequences of previous metabolic decompensations). T2D patients usually show increased urinary excretion of 2-methyl-3-hydroxybutyrate, 2-methylacetoacetate and tiglylglycine, intermediates in isoleucine catabolism (2). T2D usually have a favorable outcome, but there is a risk of death and neurological sequel 
from an acute ketoacidosis episode (3). T2D is caused by mutations in the ACAT1 gene located on the chromosome 11 222.3-q23.1. This disease is very heterogeneous at the genotype level, with at least 70 different mutations described (4).

We report herein the cases of two siblings diagnosed with T2D who were quite different in terms of onset and clinical phenotype.

\section{Case Reports}

Patient 1: Patient 1 was a boy born in the 36th week of gestation; weighing 2.400 grams. His parents were first-degree cousins. His initial neuromotor development was appropriate for his age and he had experienced four febrile illnesses without ketoacidosis. At eight months of age, he was admitted to the hospital for symptoms of respiratory tract infection and lethargy. Mechanical ventilation support was indicated at the intensive care unit. Due to the significant acetone odor in his breath, diabetic ketoacidosis was thought to be the main cause of these symptoms. The patient also had ketonuria, hyperglycemia (blood glucose: $220 \mathrm{mg} / \mathrm{dL}$ ), severe metabolic acidosis (blood pH: 6.88, $\mathrm{pCO}_{2}: 6.1 \mathrm{mmHg}$, bicarbonate: $4.9 \mathrm{mmol} / \mathrm{L}$, anion gap: 29 $\mathrm{mmol} / \mathrm{L}$ ) and lactic acidemia (blood lactic acid: $51 \mathrm{mg} / \mathrm{dL}$ ). At the initial diagnosis, drug intoxication, salicylate poisoning in particular, was suspected. However, blood salicylate levels were within normal range. The patient who did not respond to treatments for diabetic ketoacidosis, with normal blood salicylate levels and a negative toxicology screening result had blood ammonia levels of $207 \mathrm{mmol} / \mathrm{L}$. Due to this significant hyperammonemia, differential diagnosis included organic aciduria and carnitine treatment for organic aciduria was planned. Despite carnitine supplementation, bicarbonate replacement therapy and high calorie parenteral nutrition therapy; the severe metabolic acidosis was not resolved and the case required peritoneal dialysis. Extubation could be achieved only after a month due to newly developed pneumonia. During this metabolic disturbance period; sharp rises on acylcarnitines $\mathrm{C} 5: 1$ and $\mathrm{C} 5 \mathrm{OH}$ levels in addition to gross amounts of 3-hydroxy-n-butyrate, 2-methyl-3hydroxybutyrate and tiglylglycine excretion were detected in the blood and urine samples of the patient. Brain magnetic resonance imaging (MRI) demonstrated hyperintense areas involving basal ganglia and-surprisingly- brain stem. During hospitalization, skin biopsy was obtained for Şbroblast culture and measurement of both T2 and succinyl-CoA3-keto transferase (SCOT) enzyme activities. A moderate protein-restricted diet and L-carnitine supplementation with increased carbohydrate intake were recommended. Today, the patient is 18 months old and has experienced no further ketoacidosis episodes, but still suffers from neurologic involvement (spasticity) and respiratory tract involvement (chronic lung disease). Since the initiation of the treatment he has had no subsequent episodes of ketoacidosis.

Patient 2: Patient 2 is a six-year-old female and the sister of the index patient. Her clinical and laboratory evaluation was performed after the first patient's metabolic decompensation. The girl was born at term with a birth weight of 3.800 grams. She had normal neurological examination and developmental milestones. Despite the normal results of general clinical biochemistry markers (blood gas analysis, blood glucose, lactate, ammonia and urine ketones), blood acylcarnitine profiles and urinary organic acid levels were typical for T2D. Maintenance therapy including a diet low in fat, with moderate isoleucine restriction, frequent feeding and carnitine supplementation was initiated. The patient has not experienced any ketoacidosis attacks up to her current age of seven. Brain MRI revealed no abnormality. Her echocardiography results were normal after she was assessed due to hypertrophic cardiomyopathy in her younger brother.

Table I. Fibroblast acetoacetyl-CoA thiolase activities of the patient 1, in the absence and presence of potassium ions. Only the thiolase T2 is activated by potassium ions. (Fibroblast enzyme activities were determined in duplicate (different series) and mean values are given in nmol acetoacetyl-CoA $\mathrm{min}^{-1} \mathrm{mg}^{-1}$ protein) stem

\begin{tabular}{|l|l|l|l|l|l|}
\hline & $\begin{array}{l}\text { Acetoacetyl-CoA thiolase } \\
\text { activity } \\
\text { (substrate acetoacetyl-CoA } \\
\text { without K+) }\end{array}$ & $\begin{array}{l}\text { Acetoacetyl-CoA thiolase } \\
\text { activity } \\
\text { (substrate acetoacetyl-CoA } \\
\text { with K+) }\end{array}$ & $\begin{array}{l}\text { Ratio of acetoacetyl- } \\
\text { CoA thiolase activities } \\
\text { with/without K+) }\end{array}$ & $\begin{array}{l}\text { SCOT activity } \\
\text { Ratio of activities } \\
\text { of SCOT and } \\
\text { acetoacetyl-CoA } \\
\text { thiolase activity } \\
\text { with K+ }\end{array}$ \\
\hline Patient 1 & 3.83 & 4.06 & 1.06 & 4.47 & 1.10 \\
\hline $\begin{array}{l}\text { Positive control } \\
\text { SCOT deficient }\end{array}$ & 3.41 & 10.8 & 3.17 & ND & ND \\
\hline $\begin{array}{l}\text { Positive control } \\
\text { T2 deficient }\end{array}$ & 4.66 & 4.67 & 1.00 & 6.82 & 1.46 \\
\hline Negative control A & 3.81 & & 2.78 & 4.56 & 0.43 \\
\hline Negative control B & 5.22 & 10.6 & 3.43 & 5.18 & 0.29 \\
\hline Negative control C & 2.67 & 17.9 & 2.62 & 4.91 & 0.70 \\
\hline CoA: Coenzyme A, SCOT: Succinyl-CoA transferase & 6.99 & & \\
\hline
\end{tabular}


Informed consent was obtained from the patients' parents to perform skin biopsy, enzyme assays, and molecular testing, all on a clinical basis.

\section{Enzyme Assay}

The Control and patients' fibroblasts were cultured in Eagle's minimum essential medium containing $10 \%$ fetal calf serum. We assayed acetoacetyl-CoA thiolase activity in the presence and absence of potassium-ion, since T2 is the only thiolase which is activated by the ion. Immunoblot analysis was done as described before (5). In controls, twofold serial dilution samples from 30 to $3.75 \mathrm{mg}$ were electrophoresed together with the samples $(30 \mathrm{mg})$ of the patients to determine the amount of T2 protein in the patients' fibroblasts relative to that in the Control fibroblasts.

\section{Molecular Testing}

Molecular genetic investigations were performed by PCR and DNA sequence anaylsis. We tested all exons of the ACAT1 gene of the patient plus flanking intronic regions. Reference sequence for the ACAT1 gene is ENSG00000075239. Reference sequence for the ACAT1-cDNA is NM_000019.3. The samples of the parents and the siblings were analyzed for the mutation identified in exon 10 only.

\section{Enzyme Assay}

T2 enzymatic activity was reduced in patient 1's Şbroblasts. SCOT enzymatic activity was normal (Table I).

ACAT1 gene analyses of the siblings and parents have been performed as a last step of the diagnostic procedures. Mutation analysis indicated homozygosity of patient 1 and patient 2 for a missense mutation c.949 G>A in the ACAT1 gene, predicted to result in the substitution of evolutionary conserved acidic aspartic acid by asparagine in position 317 of the methylacetoacetyl-coenzyme A thiolase protein, which is encoded by the ACAT1 gene. When applied to the mutation p.Asp317Asn, the prediction program "Mutation tester" yielded the prediction of "disease causing". Both parents of the patients were found to be heterozygous for this mutation, thus confirming homozygosity for the index case and his sibling.

\section{Discussion}

T2D deficiency is a rare but serious congenital metabolism disorder that involves dysfunction of a specific step in isoleucine and ketone body metabolism, which results in the accumulation of various intermediate metabolites and organic acids $(1,3)$. The natural history of the disease tends to involve episodic exacerbations, commonly precipitated by infections, fasting or even an increase in dietary protein consumption. It manifests clinically with symptoms seen in toxic encephalopathy such as vomiting, poor feeding, seizures, abnormal tone, lethargy and even coma. One of the most important clinical properties of beta-ketothiolase deficiency for pediatricians is its tendency to be misdiagnosed as diabetic ketoacidosis or salicylate poisoning like in our index case $(6,7)$. Even though there is very severe clinical decompensation in our patient, in milder cases the clinical spectrum can vary from mild neurological symptoms to no symptoms at all (8).

In diagnosis; the blood acylcarnitine profile may provide supportive evidence for T2D as in our patients. An abnormal acylcarnitine profile should be followed up with a careful analysis of urine organic acids in order to confirm the diagnosis of T2D. On the other hand, especially for patients who have mild presentations like patient 2, the acylcarnitine profile may be normal. Some T2-deficient patients with mutant enzyme, which retains some residual activity, do not show typical urinary organic acid profile even during the acute attacks; a minority of individuals with a mutant genotype will not develop any symptoms in childhood; whether they will ever develop symptoms in their lifetime is not known $(3,9)$. The presence of urinary tiglylglycine may reflect a severe block in isoleucine catabolism at the T2 enzyme step. Therefore, the absence of tiglylglycine suggests the presence of some residual T2 activity in vivo. On the other hand; patient 2 showed urinary excretion of tiglylglycine but has not experienced any attacks as of today, despite the fact that her brother has a very severe presentation of the disease. But they share the same mutation and probably approximate values of enzyme activity.

T2D is caused by mutations in the ACAT1 gene located on chromosome 11q22.3-q23.1. $(7,10,11)$. Most of these mutations have been characterized on the basis of their residual enzyme activity. However, there was no correlation between the genotype and the clinical phenotype, and ketoacidosis episodes did not show a difference in terms of severity or frequency. Mutant siblings can present different clinical severity; as the siblings reported here did (3).

As a supportive diagnostics tool; radiological findings in those patients also resemble those of other organic acidurias. Brismar and Ozand (12) and Ozand et al. (13) reported focal high T2 signal intensity in the posterior putamen in three T2D patients. A five-year-old girl with T2D deficiency was reported by O'Neill et al. (14) with isolated focal T2 hyper intensities involving the Globus pallidus. In our case report; patient 1 showed high T2 intensity changes involving brain stem and basal ganglia and especially nuclei caudate. MRI changes involving basal ganglia and brain stem are not atypical for organic acidurias and those can mimic mitochondrial disorders such as Leigh syndrome.

\section{Conclusion}

We have described two sibling patients affected by T2D with quite different clinical presentations. The younger boy presented a very severe decompensation attack complicated by ketoacidosis coma during the $7^{\text {th }}$ month of life and he had severe sequelae after this attack. The elder sister did not experience any ketoacidosis attacks until her current age of 7 years.

The case presentations of these two patients include important messages. T2D usually has a favorable outcome, but there is a risk of death and neurological sequelae due to 
an acute ketoacidosis episode. The clinical table of our index case, which can be misdiagnosed as diabetic ketoacidosis and especially as salicylate intoxication, shows the importance of metabolic sampling in cases with deep metabolic acidosis of unknown origin which do not respond to treatment. In countries with higher rate of cousin marriages such as Turkey, deep metabolic acidosis, ketonuria and hyperammoniemia are important clues in the diagnosis of classic organic acidurias and ketosis defects. Early diagnosis of those patients and an effective treatment planning may be beneficial for the patients to go through this decompensation attack period with minimal permanent disabilities. This is especially important for the pediatricians working in emergency room and intensive care unit settings. The sister who did not experience any decompensation attacks also shows the importance of family screening. Diagnosis of female cases in particular, even if they do not show any symptoms of the disease, is important to take the necessary precautions to avoid an attack during pregnancy.

Ethics

Informed Consent: Written informed consent was obtained from the patient for publication of this case report and any accompanying images. A copy of the written consent is available for review by the Editor-in-Chief of this journal.

Peer-review: External and Internal peer-reviewed.

\section{Authorship Contributions}

Medical Practices: Melis Demir Köse, Ebru Canda, Mehtap Kağnıcı, Concept: Melis Demir Köse, Sema Kalkan Uçar, Mahmut Çoker, Design: Melis Demir Köse, Sema Kalkan Uçar, Mahmut Çoker, Data Collection or Processing: Melis Demir Köse, Ebru Canda, Mehtap Kağnıcı, Rana Işgüder, Aycan Ünalp, Analysis or Interpretation: Luzy Bahr, Corinne Britschgi, Jörn Oliver Sass, Literature Search: Melis Demir Köse, Writing: Melis Demir Köse.

Conflict of Interest: No conflict of interest was declared by the authors.

Financial Disclosure: The authors declared that this study has received no financial support.

\section{References}

1. Daum RS, Lamm PH, Mamer OA, Scriver CR. A "new" disorder of isoleucine catabolism. Lancet 1971;2:1289-90.

2. Sarafoglou K, Matern D, Redlinger-Grosse K, et al. Siblings with mitochondrial acetoacetyl-CoA thiolase deficiency not identified by newborn screening. Pediatrics 2011;128-246-50.

3. Fukao T Scriver CR, Kondo N; t2 Collaborative Working Group. The clinical phenotype and outcome of mitochondrial acetoacetyl-CoA thiolase deficiency ( $\beta$-ketothiolase or T2 deficiency) in 26 enzymatically proved and mutation-defined patients. Mol Genet Metab 2001;72:109-14.

4. Fukao T, Horikawa R, Naiki $Y$, et al. A novel mutation (c.951C_T) in an exonic splicing enhancer results in exon 10 skipping in the human mitochondrial acetoacetyl-CoA thiolase gene. Mol Genet Metab 2010;100:339-44.

5. Fukao T, Song XQ, Mitchell GA, et al. Enzymes of ketone body utilization in human tissues: protein and messenger RNA levels of succinyl-coenzyme A (CoA):3-ketoacid CoA transferase and mitochondrial and cytosolic acetoacetylCoA thiolases. Pediatr Res 1997;42:498-502.

6. Arica V, Arica SG, Dag H, Onur H, Obut O, Gülbayzar S. Betaketothiolase deficiency brought with lethargy: case report. Hum Exp Toxicol 2011;30:1724-7.

7. Elleau C, Parrot-Roulaud F, Perel Y, et al. Beta-ketothiolase deficiency: a case of ketoacidosis with hyperglycinemia. Pediatrie 1992;47:185-9.

8. Buhaş D, Bernard G, Fukao T, Décarie JC, Chouinard S, Mitchell GA. A treatable new cause of chorea: betaketothiolase deficiency. Mov Disord 2013;28:1054-6 .

9. Dipple KM, McCabe ER. Modifier genes convert "simple" Mendelian disorders to complex traits. Mol Genet Metab 2000;71:43-50.

10. Ofman R, Ruiter JP, Feenstra M. 2-Methyl-3-hydroxybutyrylCoA dehydrogenase deficiency is caused by mutations in the HADH2 gene. Am J Hum Genet 2003;72:1300-7.

11. Sass JO. Inborn errors of ketogenesis and ketone body utilization. J Inherit Metab Dis 2012;35:23-8.

12. Brismar J, Ozand PT. CT and MR of the brain in the diagnosis of organic acidemias. Experiences from 107 patients. Brain Dev 1994;16(Suppl):104-24.

13. Ozand PT, Rashed M, Gascon GG, et al. 3-Ketothiolase deficiency: a review and four new patients with neurologic symptoms. Brain Dev 1994;16(Suppl):38-45.

14. O'Neill ML, Kuo F, Saigal G. MRI of pallidal involvement in Beta-ketothiolase deficiency. J Neuroimaging 2014;24:414-7. 